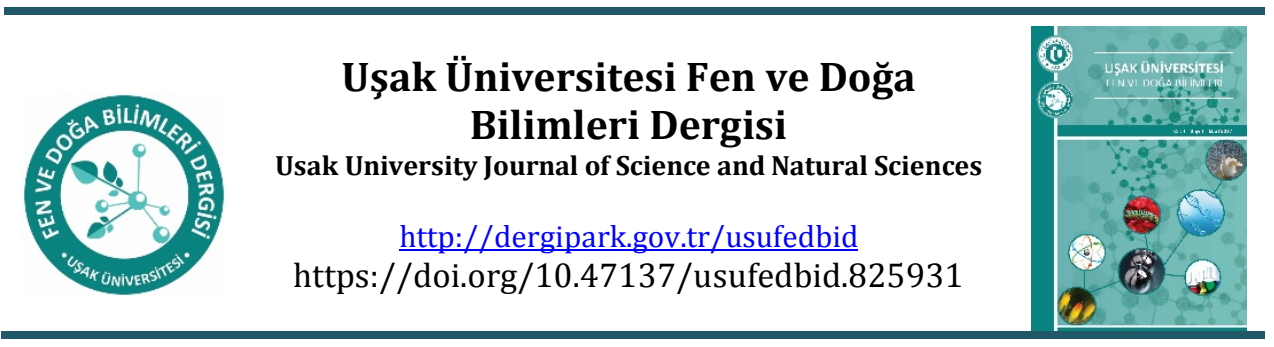

Derleme makalesi

\title{
Sığır Sürülerinde Hiyerarşik Davranışların Sürü Yönetimine Etkileri
}

\author{
Mustafa Varol $^{*}$, Sibel Alapala Demirhan \\ 1 İl Tarım ve Orman Müdürlüğü, Isparta, Türkiye \\ ${ }^{2}$ Zootekni Bölümü, Ziraat Fakültesi, Uşak Üniversitesi, Uşak, Türkiye
}

\begin{abstract}
Dairy and beef cattle, like most living communities, are a social species and have a social order. In order to be successful in cattle breeding, it is necessary to know these social behaviors well, to establish a social hierarchical order and to plan the herd management well. Social behaviors include relationships and communications among individuals such as breeding, maternal relationships or play behaviors. Understanding these behaviors provides a significant convenience in terms of care and herd management, herd stress, productivity increase and animal nutrition. The formation of a hierarchical order in the herd management is important for the individuals living in a certain social order to survive without any adversity, and to eliminate the stress, loss of productivity and physical injuries between individuals that will result from agonistic behaviors.

Herd management can be achieved by paying attention to factors such as shelter layout, cold-heat stress, and transportation, as well as by understanding the behavioral characteristics that exist between animals. With a good herd management, it is possible to produce high quality and continuous meat-milk production and to ensure efficiency by obtaining higher efficiency from cattle. Good herd management means less stress, more welfare, more yield. Hierarchical behavior, which has been among the animal behaviors that have existed since the past, should be used positively in herd management

In this study, it was prepared to determine how hierarchical behaviors affect herd management and productivity in dairy and beef cattle herds.
\end{abstract}

Keywords: Animal behavior, herd management, beef cattle, dairy cattle.

\section{Özet}

Süt ve besi sığırları çoğu canlı topluluğu gibi sosyal bir türdür ve sosyal bir düzenleri vardır. Sığır yetiştiriciliğinde başarılı olmak için bu sosyal davranışları iyi bilmek, sosyal hiyerarşik düzeni oluşturmak ve sürü yönetimini iyi planlamak gerekmektedir. Sosyal davranışlar bireylerin kendi arasında üreme, ana yavru ilişkileri veya oyun davranışları gibi ilişkileri ve iletişimleri içermektedir. Bu davranışları anlamak, bakım ve sürü idaresi, sürü stresi, verim artışı ve hayvan besleme konularında önemli bir kolaylık sağlamaktadır. Sürü idaresinde hiyerarşik düzenin oluşması, belli bir sosyal düzen içerisinde yaşayan bireylerin herhangi bir olumsuzluk yaşamadan yaşamlarını idame ettirmesi ve agonistik davranışlar sonucu meydana gelecek stres, verim kaybı ve bireyler arası fiziksel yaralanmaların ortadan kalkması için önemlidir.

Sürü yönetimi barınak düzeni, soğuk-sıcak stresi, nakil gibi faktörlere dikkat edilerek sağlanabildiği gibi hayvanlar arası var olan davranışsal özelliklerin anlaşılması sayesinde de sağlanabilmektedir. Sığırlardan

\footnotetext{
*Corresponding author: Mustafa Varol

E-mail: mustafavarol15@gmail.com

ORCID ID: 0000-0003-3468-2137
}

(C)2021 Usak University all rights reserved. 
daha yüksek verim elde edilerek kaliteli ve devamlı et-süt üretimi yapmak, verimliliği sağlamak iyi bir sürü yönetimi ile mümkündür. İyi bir sürü yönetimi demek, daha az stres, daha fazla refah, daha fazla verim anlamına gelir. Geçmişten beri var olan hayvan davranışları arasında bulunan hiyerarşik davranıșın, sürü yönetiminde olumlu şekilde kullanılması gerekmektedir.

$\mathrm{Bu}$ çalışma, süt ve besi sığırı sürülerinde hiyerarşik davranışların sürü yönetimini ve sığırlarda verim üzerine etkilerini belirlemek amacıyla hazırlanmıştır.

Anahtar Kelimeler: Hayvan davranışı, sürü yönetimi, besi sığırı, süt sığırı

(C)2021 Usak University all rights reserved.

\section{Giriş}

Tüm hayvanlar ortak beslenme, çiftleşme ve nesillerini sürdürme amacı ile gruplaşma ve sosyalleşme eğilimi gösterirler [1]. Çiftlik hayvanlarının büyük bir kısmı da çoğu canlı topluluğu gibi sosyal bir türdür ve sosyal bir düzenleri vardır. Hayvan yetiștiriciliğinde başarılı olmanın koşullarından biri de bu sosyal davranışları iyi bilmek, sürü yönetimini iyi planlamaktır. Sosyal davranışlar iki veya daha fazla birey arasındaki, ana yavru ilişkileri, oyun davranışları, üreme davranışları, birbirlerini koklamak veya vücut temasında bulunarak iletişim kurmak gibi karşılıklı ilişkileri içerir [2]. Hayvan davranışlarını anlamak; bakım ve sürü idaresini kolaylaştırması, sürü stresinin azaltılması, verim artışı, çiftleşme, döl verimliliği, beslenme, sağlık ve hayvan refahı için önemlidir. Bireyler arasındaki sosyal iletişim ve düzenin oluşması sürü içerisindeki hayvanların birbirini kabul etmesi ve hiyerarşik düzenini oluşturması ile başlar [3]. Hiyerarşi düzenini; canlı ağırlık, boynuzluluk, yaş, cinsiyet, cüsse, hastalık, huy, genetik yapı ve yaşa bağlı tecrübeler gibi birçok etmen etkilemektedir. Bir sığır sürüsündeki hiyerarşi aynı yaş ve cinsiyet grubundaki hayvanlar arasında olduğu gibi, özellikle boynuzlu hayvanlardan boynuzsuz hayvanlara, yaşlı hayvanlardan genç hayvanlara veya erkek hayvanlardan dişi hayvanlara doğru bir sosyal düzen söz konusudur. Sürüdeki bireyler, bu sosyal düzene uyduğu sürece barınacak, beslenecek ve sürü içerisine bir yer edinecektir [4].

Hayvansal üretimde sosyal hiyerarşinin, alt sıralarda kalan genetik olarak üstün bireylerin potansiyellerini ortaya çıkaramaması gibi bir takım olumsuzlukları olmasına karşın, genellikle yararlıdır. Çünkü belli bir sosyal düzen içerisinde yaşayan bireyler herhangi bir sorun olmadan yaşamadan yaşamlarını idame ettirirler. Ayrıca sosyal hiyerarşi, sürü idaresinde kolaylık sağladığı gibi mücadele davranışlarını azaltarak gereksiz enerji tüketimini, üstünlük kurma çabalarından kaynaklı yaralanmaları ve bireyler arası tehdit sonucu stres oluşumunu azaltarak bunlara bağlı verim kayıplarının önüne geçilmesini sağlamaktadır. [2].

\section{Hiyerarşik Davranışların Önemi}

Hayvanlardaki soysal hiyerarşik davranışlar ile ilgili çalışmalara uzun yıllar önce başlanmış ve önemli bulgular ortaya çıkarılmıștır. Çalıșma konumuz ile bağlantılı olarak, süt sığırcılığında sosyal davranışlar ilk kez 1853 yılında Low [5] tarafından incelenmiş, sonrasında ise yaklaşık bir asır sonra Woodbury [6] tarafından ele alınmıştır. Tam olarak sosyal hiyerarşi ilişkilerinin incelenmesi ise 1955 yılında Schein ve ark. [7] tarafından gerçekleştirilmiştir. [8]. Ülkemizde ise sosyal davranışlar, hiyerarşi ve refah konuların hakkında önceki yıllarda çok çalışma bulunmasa da son yıllarda konunun önemi fark edilmiştir. 
Ülkemizde bu tür araştırmaların geç kalmasının, hayvancılık işletmelerinin genellikle küçük ve aile işletmesi şeklinde olmasına bağlı olduğu düşünülmektedir. Bu işletmelerde az sayıda ve aynı bölmede ya da ortak merada otlayan bireyler bir birini tanıyabilir ve sorunlu hiyerarşi davranışları çok görülmeyebilir. Örneğin bir sığır ortalama 50-70 adet bireyi tanıyabilir ve sürüden ayrılsa bile bir süre hatırlayabilir [9]. Bu tip ișletmelerde işletme başına düșen hayvan sayısı az olması sebebiyle basit bir sosyal düzen vardır. Bu tip sürülerde dominant veya lider olarak adlandırılan bir sığır mevcut olup, aralarında sağladıkları üstünlük oranında liderin altında hiyerarşik düzeni oluşturan tüm bireyler arasında da dominans ilişkisi vardır. [4].

Sığır sürülerine dışarıdan bakıldığında, lider olarak adlandırılan hayvan fiziksel üstünlük, yaş, canlı görünüm, başını dik tutuş ya da diğer bireylerden üstünlük sağladığı boynuz varlığı, ağırlık ya da türe özgü morfolojik üstünlük ile sürü içerisinde ilk göze çarpan ve dikkati çeken hayvan olarak tanımlanmaktadır. Bu tip hayvanlara diğer canlılardaki gibi baskın yani "alfa hayvan" denir. Alfa hayvan sürüde ortak kullanılan yemlik, suluk, dinlenme ve yataklık gibi alanlara geç katılsalar bile önceliğe sahiptirler. Baskın hayvanın altında yer alan, lidere itaat etmek zorunda kalan hayvanlara ise "omega hayvan" denir [4]. Bu özellikteki çiftlik hayvanları, lider hayvana veya sosyal düzen içerisinde kendinden üstün kabul ettiği sürüdeki diğer hayvanlara saygısını ve çekincesini belirtmek için kulak ve başlarını her zaman için daha aşağı seviyede tutmak zorundadırlar. Hiyerarşik düzenlerde yaklașık böyle bir durum söz konusu olup, bunun aksi bir hareket yapması durumunda ortaya çıkacak kavgaya memeli beyni temel çalışma mekanizması olan; karşılık vermek(Savaş) veya kaçmak(Kaç) şeklinde tepki göstermek mecburiyetinde kalmaktadır $[4,9]$.

Çiftlik hayvanları kararlarını ve davranışlarını diğer hayvanlar gibi mantıksal değil içgüdüsel olarak, kalıtım ve çevrenin etkisiyle belirlerler ve bunları etkileyen birçok etmen vardır [10]. Sığırlardaki bu tür davranışları etkileyen etmenler ırk, tür, cinsiyet ve bireysel varyasyon olarak sıralanabilir. Genetik parametreler açısından agresif davranışlar sergileme ve bu tarz davranışlara maruz kalma olarak düşünüldüğünde ise agresif davranışlar sergilemenin daha yüksek bir kalıtım derecesine sahip olduğu bilinmektedir [11]. Ayrıca yapılan bir çalışmada; ırklar arasında baskınlık karakterleri olduğu, Angus ırkı ineklerin Shorthorn ırkı ineklerden daha baskın olduğu ve her ikisinin de Hereford ırkı ineklerden daha baskın olduğu, diğer bir çalışmada ise Siyah-Beyaz x Jersey melezlerinin Avrupa Bizonundan daha agresif ve sosyal gerilime daha dayanıklı olduğu bildirilmiştir (12). Davranışsal olarak ise sosyal sıralamada önde olmak ve grup içinde üstünlük kurmak için özellikle sürüdeki erkekler yeri boynuzlama, eşeleme, tehdit edici yan bakış ve ani tepki vermeye hazır bir duruş gösterir. Başın aşağıda tutularak rakibe dik bakma, arka ayakları öne çekerek dik durması ve bögürerek başıyla diğer hayvana boynuz atması da en fazla görülen üstünlük kurma çabalarındandır. Genellikle erkek hayvanların bulunduğu besi işletmelerinde bu tip davranışlar daha çok görülmekte, süt sığırcılığı işletmelerinde daha az karşılașılmaktadır. İnekler arasında kavga davranışı nadiren ortaya çıkmakta, genellikle yem mücadelesi için karşılaşılan bu durumda ineklerin birbirlerinin yan taraflarını hedef alarak saldırdıkları veya toslaştıkları gözlenmektedir $[4,9,13,14]$.

Hayvansal üretimde bu tür davranışlar sürü içerisindeki stres yoğunluğunu arttırmakta, işletme için önemli ekonomik kayıplara neden olmaktadır $[2,15,16]$. Ancak merada ve meradan dönüş zamanlarında, ahır giriş ve çıkış zamanlarında ya da sağım zamanlarında insan faktörünün de etkisi ile sürüdeki hiyerarşik sıralamanın ortadan kalktığını görmek mümkündür. Erkek ve dişilerin karıșık olarak meraya gönderildiği sürülerde ise doğal ortamlarındaki hiyerarşik dağlıma benzer olarak 2 yaş ve üzerindeki boğalar bütün 
sürüye egemen olup, aralarında ise, fiziksel üstünlükleri oranında bir hiyerarşik konuma sahiptirler. 1-2 yaş arasındaki tosunlar ise, düve ve dişi danalara hâkimiyet kurmalarına karşıllk, ergin ineklere karşı etkisiz kalmakta ve onlara da hükmedebilmek için sık sık ergin ineklerle kavga etmektedirler [4].

Sosyal hiyerarşi oluşmuş sürüye o yıl giren genç hayvanların ve dişarıdan getirilen yabancı hayvanların giriși kısa süreli bir kargaşa oluşturmakta, sürüye yeni giren hayvanların hiyerarşide yerini bulmalarıyla birlikte genellikle son bulmaktadır $[3,16,2]$. Birleștirilen sürülerde bir grup içerisinde lider ve baskın olan sığır, başka bir grupta baskın bireyi yenmeyi göze almazsa ancak itaatkâr olduğu takdirde kabul görmektedir. $\mathrm{Bu}$ nedenle sürüye yeni girenler ilk birkaç gün sürüden ayrı bir yerde gruplaşarak durmakta, arada bir yerli sürünün fertleri ile vücut teması ve koklaşmak suretiyle tanışma davranışları sergilemektedirler. Sürüye yeni dahil olan sığır grubu ferdi olarak kabul edilmektedir. Her bir yeni birey, eski sürünün fertlerine itaat ettiğini gösterir davranışları sergilediği takdirde sürüye kabul edilmekte, yem yemesine, yataklık alanlarından yararlanmasına izin verilmektedir. Agresif davranan yeni birey ise, sürüden dışlanmakta yem yemesine veya su içmesine izin verilmemektedir. Ancak kavga davranışı ile üstünlük sağlayabilirse, üstünlük oranında sosyal düzende bir yer edinmektedir $[2,4,36,37]$. Birleşme süreleri sürüye göre değișmekle birlikte sürülerin içindeki tecrübeli birey sayısının yoğunluğuna göre değișiklik göstermektedir. Bouissou [17] yaptığı bir çalışmada farklı bölümlerden bir araya getirilen düvelerin \%70' inin ilk on dakikada, toplamda ise bir saat içerisinde sosyal düzende yer aldıklarını, sürü içerisindeki deneyimli bireylerin bu sıralamayı daha az mücadele ile daha kısa sürede tamamladığını bildirmiștir. Diğer taraftan, daha büyük popülasyona sahip sığır sürülerinde ise sosyal düzen daha karmaşıtır. Sürü yönetimi için popülasyonu ve gruplaşmaları daha dikkatli incelemek gerekmektedir. Grupların oluşmasında vücut cüssesi, boynuz, yaş, cinsiyet ve mizaç gibi faktörler önemli bir etkiye sahiptir. Fiziksel olarak üstün olan; cüssesi büyük, canlı ağırlı̆̆ı yüksek, cidago, sağrı ve ön kürekler arkası göğüs çevresi genişliği fazla olan inekler, sürü içerisindeki her grupta sosyal olarak iyi bir yer alma ihtimalleri yüksektir. Grup içerisindeki genç bireylerin genotipik özellikleri ve çevre etkisiyle sosyal sıralamalarında kısa süreli değişiklik olabilir, fakat bir süre sonra yaşayan hayvanlar arasında oluşan sosyal hiyerarşideki sıralamanın genellikle sabit kaldığı ifade edilmektedir [4]. Sürü içerisindeki sosyal sıralamanın canlı ağırlık [18], göğüs genişliği [19] ve cidago yüksekliği [20] ile pozitif yönde bir ilişkisinin olduğunu bildirmiştir.

Sığırlar arasındaki kavga tüm ruminantlarda olduğu gibi kafa kafaya toslaşma şekildedir [21]. Büyükbaş ve küçükbaş hayvanlar genellikle alınları ya da boynuzları ile birbirlerine saldırır. Bu yüzden sosyal hiyerarşinin oluşumuna hayvanın boynuzluluğu en önemli faktör, canlı ağırlığı ve yaşı diğer önemli faktörler olarak bilinmektedir. Hiyerarşinin üst noktalarında boynuzlu hayvanlar olup yaşça küçük ve düşük canlı ağırlığa sahip olsalar dahi bazı hayvanlar sahip oldukları boynuz sayesinde sosyal sıralamada üst noktalarda kendilerine yer edinebilirler. Hayvanlarda boynuzun varlığının yanında boynuzun şekli ve büyüklüğünün de baskınlıkta önemli bir faktör olduğu bilinmektedir. Hayvanlarda yaşla beraber kazanılan tecrübe ve artan canlı ağırlık, hiyerarşide yükselmelerine neden olmaktadır. Buna ek olarak fertlerin çoğunluğunun boynuzsuz olduğu bir sürüde boynuzlu bir sığır her zaman için sosyal olarak kendine iyi bir yer edinebilmektedir. Düveler ve genç danalar, gruplaşmanın en bariz olarak gözlendiği çă̆ grupları olup, günün önemli bir kısmında kendi aralarında ve ayrı bir yerde toplu olarak hareket ettikleri rahatlıkla gözlenebilmektedir. Bu gibi sürülerde yaşlı inekler, genç inekler, düveler, diși danalar olmak üzere hiyerarşik bir düzen dâhilinde sıralanmaktadır. $[22,23,24,25,26,27,28,29,30,2,3]$. Ayrıca sürü içerisindeki baskın annelerinin yavruları da baskın olma eğilimindedir [31,32,13]. Bu da baskın yavruların kaynakları daha iyi 
kullanması, daha çabuk kilo alması ve daha verimli olmasını sağlamaktadır $[12,13,33,34,35]$.

Sığırlar arasındaki sosyal ilişkiler, ülkemizde yeni bir konu olmakla beraber, sürü idaresinde dikkate alınmayan ancak süt, et ve özellikle döl verimi gibi verimler üzerinde önemli bir etkiye sahip çevre faktörü olarak karşımıza çıkmaktadır. Sürü idaresinin iyi planlanmaması veya yönlendirilmemesi sonucu ortaya çlkan sosyal stres, verimlilik adına birçok olumsuzluğun kaynağı olarak görülmektedir. Diğer konularda da bahsedildiği gibi, sığırlar bedensel ve psikolojik olarak rahat ettiği sürece verimli olacaktır. Bu noktadan hareketle sürünün veya sürü içerisindeki sığırların sosyal strese maruz kalmasını önleyecek tedbirlerin alınması gerekmektedir. Yetișkinlerle herhangi bir temas kurmadan aynı cinsiyetten genç gruplar halinde yetiștirilen hayvanlar, ergenlik çă̆ında çok geç dönemde baskınlık ilişkileri sergilemektedir [38]. Sosyal olarak güçlü bir sürü arzu ediliyor ise, sı ğırların genç yașlardan itibaren bir arada büyümelerine ve devamlı surette vücut temasında bulunmalarına izin verilmelidir. Birbirinden ayrı bölmelerde büyütülen sığırların daha sonra bir araya getirilmeleri halinde, birbirleri ile agresif davranışlara girdikleri, sosyal düzenin oluşmasının bir arada büyüyen sığırlara oranla daha uzun zaman aldığı gözlemlerle tespit edilmiştir [4,39,40].

Doğal yaşamdaki hayvanlar daha geniş bir alanda yaşamlarını sürdürdükleri için kaynakların kullanımında bağımsız olabilmektedirler. Ancak sürü halinde yaşayan çiftlik hayvanları nispeten sınırlı çevre koşullarında yaşamlarını sürdürmektedirler. Hayvanları dar alanlarda sınırladığımızda veya kapattığımızda, onların doğal olarak olușturdukları bireysel mesafeleri azalttığımızda tüm sürü boyunca stres yaşandığını görürüz. Bunun sonucunda başat hayvanlar üstünlüklerini korumak için daha fazla çaba harcayacak, tepkilerinde daha saldırgan olacaklardır. İtaat eden hayvanlar da öncekinden daha sinirli, ürkek olurlar ve bu durum tüm sürüye yayılır. Sürü içerisinde gerek gerekse ahır durağı değiștirilen bir ineğin sosyal strese maruz kaldığı bunun da veriminde düşmeye yol açtığı bilinen bir gerçektir. Bu nedenle yer değiștirme işleminin mümkün olduğunca yapılmamasına veya yer değiștirme zorunluluğu var ise, ferdi olarak değil sığırların grup olarak hareket ettirilmelerine özen gösterilmelidir [21,2,41].

\subsection{Hiyerarşinin beslenmeye etkileri}

Hayvanlar arasındaki hiyerarşi ve sosyal diziliș, mera veya çayırda yeteri kadar yem ve su sağlandığı takdirde üretimi önemli ölçüde etkilemese de kapalı yetiştirme koşullarında etkisinin çok daha fazla olduğu görülmektedir. Özellikle, sı̆̆ırlar kış bölmelerine alınacağı zaman damızlık olacak düvelerin, genç boğaların ve zayıf dișlere sahip ineklerin, ayrı beslenmelerini gerektirir. Bu yüzden sürü içerisindeki sosyal diziliş, sınırlı yemleme koşullarında da büyük önem kazanır [39].

Yapılan çalıșmalar sığırların sosyal sıralaması ile beslenme davranıșı arasında kesin ve önemli bir ilişki olduğunu göstermiştir. Baskın bireyler yemliklerde ve yemliğe yakın yerlerde toplanır ve özellikle yem sınırlıysa istedikleri yemleri ilk yiyen onlar olur. İtaat eden bireyler ise yemlikten uzaklaşır, gece veya yemlikte başka hayvan olmadığı zamanlarda yemleri yiyebilir ya da aç kalırlar. Bu yüzden özellikle yemleme esnasında hayvanların birbirleri ile vücut teması yaparak yemlenmelerini sağlamak gerekmektedir. Yemlenen sığırların vücut temaslarını engelleyecek düzenekler sürekli rekabet halinde olmaları hatta kavga etmelerine yol açmaktadır. Bu yüzden çiftlik hayvanlarında sosyal hiyerarşi ve agresif davranışlar verimlere doğrudan veya dolaylı olarak etki edebilmektedir. Bu konuda işletmelerde kullanılan sı̆̆ırların başını yemleme bölümüne çıkardıkları ama geriye çekemedikleri, vücutlarının serbest olduğu kilit sistemleri, 
hayvanların vücut teması için ideal ortam hazırlayarak rekabet faktörlerini ortadan kaldıracaktır $[2,4,8,42,43,44]$.

Yapılan bir çalışmada rasyondaki enerji seviyesinin artırılması bir takım agresif davranışların ortaya çımmasına neden olabileceği belirtilmiştir. Bu da hem sürü idaresini zorlaștırmakta özellikle yemleme sırasında rekabetçi ortamı oluşturmakta, dolayısı ile diğerlerinin yemlenmesini engellemekte ve buna bağlı olarak gelişimlerini sınırlamaktadır. Özellikle bu gibi agresif davranışlar kesim öncesi hayvanların yaralanmalarında ve dolayısıyla karkas kalitesini düşürmektedir. Bu bakımdan agresif hayvan davranışları bir takım idari tedbirlerle kontrol altına alınmaması, yapılan besinin ekonomikliğinin kaybolmasına neden olacaktır [39]. Özellikle ülkemizde sayısı giderek artan kültür ırkı sığırlarda tüm bu bahsedilen olumsuz koşulların etkisi daha fazla görülmektedir. Bu bakımdan sürüdeki hiyerarşik oluşumun takip edilerek sosyal stresin önlemesi ve yeterli konfor alanı oluşturularak üstünlük davranışlarının azaltılması gerekmektedir. Mücadele davranışının azalması ve konfor alanının artması ile geviş getirme süresi artarak, yemden yararlanma daha fazla olacaktır. Bu da daha çok ve daha ekonomik süt ve et üretimi sağlayacaktır $[2,4,16]$.

\subsection{Hiyerarşinin Döl ve Süt Verimine Etkileri}

Sığır sürülerinde hiyerarşik davranışların etkilerinin fazlaca görüldüğü alanlardan biri de döl ve süt verimidir. Özellikle süt yönlü yetiştiricilik yapılan işletmelerde döl ve süt verimi önem arz etmektedir. Çok görülmese de hiyerarşik davranışların olumsuz etkileri bu işletmelerde en aza indirilmelidir.

Alvarez ve ark. [45] hiyerarşinin üst sıralarından alt sıralarına doğru kızgınlık gösterme ve gebe kalma bakımından bir sıralamanın olduğunu belirtmektedirler. Macmillan ve ark. [46] yapmış olduğu bir çalışmada Yeni Zelanda' da 200'den fazla inekten oluşan büyük sürülerde sosyal stresin bir sonucu olarak genç ineklerde doğurganlığın azaldığını ve kısa östrus döngülerinin ortaya çıtığı tespit edilmiştir. Benzer olarak, Boissou [17] yapmış olduğu bir çalışmada büyük sürülerde döl verim problemlerinin ortaya çıkabileceğini, gebe kalma oranında \%10'luk bir azalma ve 2 yaşına gelmiş ama hala östrus göstermeyen hayvanların olduğunu bildirmiştir.

Sürü içerisinde yalnızca östrusta ve gebe olan hayvanların sosyal sıralamadan hormonların etkisi veya annelik içgüdüsünün ön planda olmasıyla etkilenmediği, ancak buzağı doğduktan sonra sosyal sırasına geri döndüğü görülmüştür [8]. Burada dikkat edilmesi gereken nokta bilindiği üzere laktasyondaki inekler genellikle daha çekingen olurlar. Baskın olma eğiliminden çok, annelik içgüdüsü doğrultusunda sosyal davranışlarda bulunurlar. Bu yüzden sosyal sıralaması oluşmuş sürülere yeni doğum yapmış ineklerin katılmasında dikkatli olunmalıdır. Hatta bu ineklerin daha az baskınlık kurma yönünde olan bireylerle birlikte ayrı bir gruba alınması sürü içerisindeki sosyal stresi azaltır $[50,8]$.

Süt veriminde de benzer olarak hiyerarşik sıralamalar iyi yönetilmediği takdirde olumsuz etkiler ortaya çıkmaktadır. Özellikle sağım ünitesinde, kişisel alanlarını ihlal etme korkusuyla dominant hayvanların yanında duran ineklerin daha az süt ürettiği gözlemlenmiştir [51]. Sürü içerisindeki sosyal sıra davranışlarının sonucu oluşan stresin süt veriminde $\% 5^{\prime}$ lik bir düşüş meydana getirdiği bildirilmektedir [7,8,44]. Çevresel etkilerden çok çabuk etkilenen süt veriminde ancak sürüde stres faktörü olmadan, dinlenme ve konfor seviyesinin yükselmesiyle gerçek verim seviyelerine ulaşılmaktadır. 
İnek mücadele davranışına girmeden, stres faktörü olmadan yatarak dinlendiğinde meme bezinde kan akışı \%20-25 artmakta, böylece yemden yararlanma ve süt veriminde yükselme olmaktadır. Yapılan araștırmalara göre yatma süresinin günde bir saat daha fazla olması durumunda süt veriminde 0.9-1.5 kg arasında bir artış olduğu bildirilmiștir $[47,48,49]$.

Hiyerarşik davranışların olumuz etkilerinin ortadan kaldırılması ve olumlu etkilerinin kullanılması için iyi bir sürü yönetimi planlanarak uygun yetiștirme sistemi, uygun yerleșim sıklığı, hayvanların yaș ve fizyolojik dönemlerine göre gruplandırılması, yeni hayvan girișlerinin kısıtlı ve kontrollü yapılması, sürüde sürekli huzursuzluğa strese neden olan hayvanların verimlerine de bakılarak gerekirse sürüden ayıklanması ve hayvanların kaynaklardan eșit biçimde yararlanmasını sağlayıcı tedbirlerin alınması önemli uygulamalar olarak ilk etapta uygulanabilir [2,52].

\section{Sonuç}

Süt ve besi sığırcılığında hiyerarşi ve sürü yönetimi, ekonomik olarak etkinin en fazla görüldügü konulardır. Bu yüzden sosyal hiyerarşinin, bazı verim özelliklerine olumsuz etkisini en aza indirebilmek için hayvan davranışlarının dikkatle takip edilmesi ve iyi bir sürü idaresine ihtiyaç duyulmaktadır [42]. Aynı zamanda hayvanların verimlerine sosyal sıralamadaki yerlerinin de etkisinin olduğu bilinmeli, damızlık niteliği iyi olduğu halde sosyal sıranın en altlarında yer aldığı için verimsiz olduğu düşünülen hayvanların damızlıktan çıkarılmasını önlemek için ıslah programlarında sosyal sıralamanın bir çevre faktörü olarak gözetilmesi gerekmektedir.

Ülkemizde, süt ve besi sığırı sürülerinde hiyerarşik davranışların sürü yönetimine ve verime olumlu veya olumsuz etkisini ortaya koyma amaçlı yeterli sayıda çalışma bulunmamaktadır. Son yıllarda artan nüfus ve beslenme ihtiyaçları doğrultusunda hayvan verimlerini arttırıcı unsurların tamamının dikkate alınması gerekmektedir. Sığırlar bedensel ve psikolojik olarak rahat ettiği, hiyerarşik düzeni oluşturduğu ve sosyal stresten uzak olduğunu zaman daha verimli olacaktır.

Elde edilen veriler değerlendirildiğinde hayvanlar arası var olan hiyerarşinin sürü yönetimine olumlu etkisi olduğu sonucuna ulaşılmıştır. Sosyal hiyerarşik davranışlar ile sürü içi düzenin sağlanması gerçekleşmektedir. Hayvanlar arasında agresif davranışların sergilenmesi ve düzeyi noktasında varyasyon görülmektedir. $\mathrm{Bu}$ varyasyonların belirlenmesi için ıslah çalışmalarında hayvanları agresif davranışlar anlamında bireysel olarak irdeleyen hayvan mizacı çalışmalarına ihtiyaç duyulmaktadır.

Sonuç olarak besi ve süt sığırı işletmelerinde sürü idaresi ve işletme karlılığı için sığırların mizaç özellikleri iyi bilinmeli ve takip edilmelidir. Sosyal etkileşimleri, hiyerarşi ilişkilerinin takibi yapılmalıdır. Hiyerarşik davranışlar iyi takip edildiğinde sürü yönetimine olumlu katkı sağlamaktadır.

\section{Kaynaklar}

1. Göncü KS. Barınak planlama ile sürü idaresi açısından hayvan davranışları ve bunun sı̆̆ır yetiştiriciliği optimizasyonunda kullanımı. 4. Ulusal Zootekni Bilim Kongresi;2004; 1-4 Eylül 2004, 240-246: Isparta.

2. Tölü C, Savaș T. Çiftlik hayvanlarında sosyal sıra ve antagonist davranışlar. Hayvansal Üretim Dergisi, 2006; 47(2):26-31. 
3. Karaağaç F. Entansif koşullarda yetiştirilen yumurtacı tavuklarda ve besi kuzularında gözlenen anormal davranıșlar. Sağlık Bil. Enst. Zootekni Anabilim Dalı, [Doktora tezi]. İstanbul; İstanbul Üniversitesi; 2002

4. Anonim. Sığırlarda sosyal davranıș.2020a. https:/amasyadsyb.org/public/docs/045_suru_idaresinde_basari.pdf. Son erișim tarihi:10.06.2020.

5. Low D. On the domesticated animals of the British Islands. 1853. Boston.

6. Woodbury AM. Changing the "hook-order" in cows. Ecology, 1941;22:410.

7. Schein MW, WH Fohrman. Social dominance relationships in a herd of dairy cattle. Brit. J. Anita. Behav. 1955; 3:45.

8. RC Lamb. Relationship Between Cow Behavior Patterns and Management Systems to Reduce Stress Journal of Dairy Science, 1976 ; 59, (9): 1630-1636.

9. Anonim. Sığır davranışları.2020b. http://cdn.istanbul.edu.tr/FileHandler2.ashx?f=sigir-davranislari.pdf. Son erişim tarihi:11.06.2020.

10. Grandin T, MJ. Deesing Chapter 1 - Behavioral Genetics and Animal Science. Genetics and the Behavior of Domestic Animals (Second Edition) 2014; Pages 140

11. Akbaş A. Çiftlik hayvanları davranışlarının genetik parametreleri. Erciyes Üniversitesi Veteriner Fakültesi Dergisi, 2013;10(3): 193-200

12. Wagnon KA, RG Loy, WC Rollins, FD Carroll. Social dominance of a herd of Angus, Hereford and Shorthorn cows. Anim. Behav. 1966;14:474-479.

13. BF Sowell, JC Mosley, JGP Bowman. Social behavior of grazing beef cattle: Implications for management. Journal of Animal Science, 2000; 77:1-6.

14. Anonim. Hayvan Davranışları. 2020c. https://avys.omu.edu.tr/storage/app/public/satasev/110425/Hayvan_Davrani slari_ders_notlari.pdf. Son erișim tarihi: 10.06.2020.

15. Barroso FG, Alados CL, Boza J. Social hierarchy in the domestic goat: effect on food habits and production. Appl. Anim. Behav. Sci., 2000;(69): 35-53.

16. Tölü C, Savaş T. Süt keçilerinde agonistik davranışlar ve yetiştirme problemleri. Süt Keçiciliği Ulusal Kongresi; 2005; 26-27 Mayıs 2005, İzmir: 89-94.

17. Bouissou MF. Social relationships in domestic cattle under modern management techniques, Italian Journal of Zoology,1980;47;(3-4):343-353

18. Sołtysiak T, Nogalski Z. The effects of social hierarchy in a dairy cattle herd on milk yield. Pol. J. Natur. Sc., 2010;25(1): 22-30.

19. Beilharz RG, Mylrea J. Social position and behaviour of dairy heifers in yards. Anim. Behav. 1963;(11):522.

20. McPhee CP, G McBride, JW James. Social behavior of domestic animals. III. Steers in small yards. Anim. Prod.,1964;(6):9.

21. Cengiz F. Sığırların ve koyunların davranışları. Eskişehir; Anadolu Üniversitesi Yayın No: 2332;(2): 20-41.2013.

22. Dawkins R. Gen bencildir-The selfish gene. Oxford University Pres;1976. Çeviri: Asuman Ü. Müftüoğlu, Tübitak popüler bilim kitapları 19, 4. Basım, Mayıs 2001.

23. Conway MLT, Blackshaw JK, Daniel RCW. The effects of agonistic behaviour and nutritional stress on both the success of pregnancy and various plasma constituents in Angora goats. Appl. Anim. Behav. Sci. 1996; (48): 1-13.

24. Pusey A, Williams J, Goodali J. The influence of dominance rank on the reproductive success of female chimpanzees. Science, 1997;(277): 828-831.

25. Drickamer LC, Arthur RD, Rosenthal TL. Predictors of social dominance and aggression in gilts. Appl. Anim. Behav. Sci., 1999; (63):121-129.

26. Cote SD. Dominance hierarchies in female goats: stability, aggressiveness and determinants of rank. Behaviour., 2000;(137):1541-1566. 
27. Cote SD, Festa-Bianchet M. Reproductive success in female goats: the influence of age and social rank. Anim. Behav., 2001;(62):173-181.

28. Phillips CJC, Rind MI. The effects of social dominance on the production and behavior of grazing dairy cows offered forage supplements. J. Dairy Sci, 2002;(85): 51-59.

29. Tölü C, Savaş T. Factors affecting development of rank-order in goats. The second joint meeting of Departments of Animal Science of the Balkan countries associated with the 32 nd Annual Session of Scientific Communications of the Bucharest Faculty of Animal Science,2003; 15-17 Oct. 2003; Romania.

30. Holand Ø, GjØstein H, Losvar A, Kumpula J, Smith ME, RØed KH, Nieminen M, Weladji RB. Social rank in female reindeer [Rangifer tarandus]: effects of body mass, antler size and age. J. Zool.,2004; (263): 365-372.

31. Tyler SJ. The behaviour and social organization of the New Forest ponies. Anim. Behav. Monogr,, 1972;(5):87-196.

32. Clutton-Brock TH, SD Albon, FE Guiness. Great expectations: Dominance, breeding success and offspring sex ra-tios in red deer. Anim. Behav., 1986;(34):460-471.

33. Broom DM, JD Leaver. Effects of group-rearing or partial isolation on later social behaviour of calves. Anim. Behav., 1978;(26):1255-1263.

34. Bennett IL, VA Finch, CR Holmes. Time spent in shade and its relationship with physiological factors of thermoregulation in three breeds of cattle. Appl. Anim. Behav. Sci., 1985; (13):227-236.

35. Bennett IL, CR Holmes. Formation of a feeding order in a group of cattle and its relationship with grazing behaviour, heat-tolerance and production. Appl. Anim. Behav. Sci., 1987;(17):9-18.

36. Jameson KA, Appleby MC, Freeman LC. Finding on appropriate order for a hierarchy based on probabilitic dominance. Anim. Behav, 1999; (57):991- 998.

37. Pedersen LJ, Heiskanen T, Damm BI. Sexual motivation in relation to social rank in pair-housed sows. Anim. Reprod. Sci, 2003;(75): 39-53.

38. Bouissou MF. Etude du diveloppement des relations de dominancesubordination chez les jeunes bovins i I'aide d'e'preuves de com pPtition alimentaire. Biol. Comp., 1977; (2): 213-221.

39. Bozkurt Y, Özkaya S. Yarı açık besi sistemlerinde yüksek enerjili yemleme seviyesinin sığırlarda agresif davranışlar üzerine olan etkileri. 4. Ulusal Zootekni Bilim Kongresi;2004; Eylül 1-3 2004, 234-238: Isparta

40. Craig JV. Domestic animal behavior : causes and implications for animal care and management Prentice-Hall, Englewood Cliffs, 1981:302-307; NJ.

41. Çavuşoğlu Y S, Akyürek H. Koyunlarda ve keçilerde beslenme davranışları. Harran Tarım ve Gıda Bilimleri Dergisi.2018; (22): 137-151.

42. Demirören E. Hayvan davranıșları. İzmir; Ege Üniversitesi Ziraat Fakültesi yayınlarl;2002.

43. Albright JL. Let cow sociology help you plan a feeding system. Successful Farming,1974;(72):1.

44. Friend TH, CE Polan. Effects of social rank on feeding behavior and free stall utilization by cows. J. Dairy Sci. 1973;(56):668.

45. Alvarez L, Martin GB, Galindo F, Zarco L. Social dominance of female goats affects their response to the male effect. Appl. Anim. Behav. Sci. 2003;(84): 119-126.

46. Macmillan KL, JD Watson. Short estrous cycles in New Zealand dairy cattle. J. Dairy Sci. 1971;(54):1526.

47. Rulquin H, Caudal JP. Effects of lying or standing on mammary blood flow and heart rate of dairy cows. Ann. Zoo,1992;41(1):101 
48. Grant R. Taking advantage of natural behavior improves dairy cow performance. Proc. 8th Western Dairy Management Conference;2007; March 7-9, 89-101: Reno NV

49. Ayyılmaz T, Uzmay C, Kaya İ. Süt sığırlarında inek konforu esaslı durak konforu tasarımı. Hayvansal Üretim, 2011;52(2): 46-57.

50. Arave CW, JL Albright, DH Yungblut, PV Malven. Social status and physiological traits as affected by group interchange of dairy cows. J. Dairy Sci. 1973;(56):667.

51. Abramowicz P, Brzozowskı P, Gołębıewskı M. Praktyczne aspekty społecznych zachowań bydła. Med. Weter. 2014;70(2):90-93.

52. Andersson M, Schaar J, Wiktorsson H. Effects of drinking water flow rates and social rank on performance and drinking behaviour of tied-up dairy cows. Livest. Prod. Sci.,1984; (11): 599-610. 